\title{
Intracranial sewing needles: review of 13 cases
}

\author{
K. A B B ASS I OUN, N. O. A MELI, A N D A. A. MOR SHED \\ From the Departments of Neurosurgery, Darioush Kabir and Pahlavi Medical Schools, \\ University of Tehran, Iran
}

SUMMARY Three new cases of intracranial sewing needles are reported and are reviewed with 10 other published cases. These needles must have been introduced in infancy before the closure of fontanelles. The intention, at least in most cases, has been infanticide. Except in one case which the mother reported and two cases found at necropsy, the others were diagnosed by skull radiography. Headache and epilepsy were the main symptoms and they often appeared when the patient had reached adulthood. Removal of the needles lessened the symptoms.

Isolated cases of intracranial sewing needles have been reported since 1914 (Gerlach and Jensen, 1958). This rare type of child abuse demonstrates that cruelty to children is not a new phenomenon, nor is it exclusive to western societies. We have been able to find 13 cases, nine in the medical literature (Meixner, 1914; Haun, 1927; Gerlach and Jensen, 1958; Askenasy et al., 1961; Ameli and Alimohammadi, 1970), one in the lay press (Dimitrijevic, 1971), and the three cases reported here.

Of these 13 cases there were three from Germany, two from Hungary, one from Poland, one from Yugoslavia, one from USA, and five from Iran.

In Moslem countries where, until recently, polygamy was widespread, abuse of children by other wives was common. Introduction of needles into the chest and abdomen was commonly reported in the newspapers (Ameli and Alimohammadi, 1970). Sadegh Hedayat (1951), a famous contemporary Iranian writer (1902-1951), in one of his short stories describes an infertile woman living in western Iran whose husband marries a second wife. The children of this second marriage were killed by the first wife soon after birth with insertion of safety pins through the fontanelles. A colleague of ours who comes from the north-western part of Iran told us that his mother had mentioned that in her youth there were rumours that this method of infanticide was practised by some women in their district. Brouardel (1897), quoted by Gerlach and Jensen (1958), described the case of a French midwife

Address for reprint requests: Dr K. Abbassioun, Darioush Kabir Medical School. Amirabad Avenue, Tehran, Iran.

Accepted 24 April 1979 who had killed about 20 new-born babies by this means.

Of the five Iranian cases at least three came from the north-west of Iran. Two of these have been reported previously (Ameli and Alimohammadi, 1970). We now report three new cases.

\section{Case reports}

CASE 1 (CASE 11 OF TABLE)

A man, aged 24 years, was the eighth child of a family of nine siblings, the seventh of his mother. The first wife had died leaving only a son. The patient's mother gave birth to six daughters before having the patient and later another son. The whole family lived in a small town in the northwest of Iran (incidentally the same town where case 8 in the Table lived).

The patient had attacks of headache for six years. Six months before admission to our department, he had been involved in a fist fight which caused severe headache. Skull radiographs showed two intracranial sewing needles. He was admitted to a local hospital and was operated on by a general surgeon in an attempt to remove the needles through solitary burrholes. This was not only unsuccessful but resulted in a right hemiparesis and aphasia.

During the next four months he made steady improvement both in his speech and motor deficits. Although his organic symptoms were gradually improving, psychologically he became severely obsessed by the presence of the needles in his head. He was admitted to Darioush Kabir Hospital in October 1978. On admission he was alert and co-operative with right spastic hemiparesis which was more obvious in the face and arm. His 


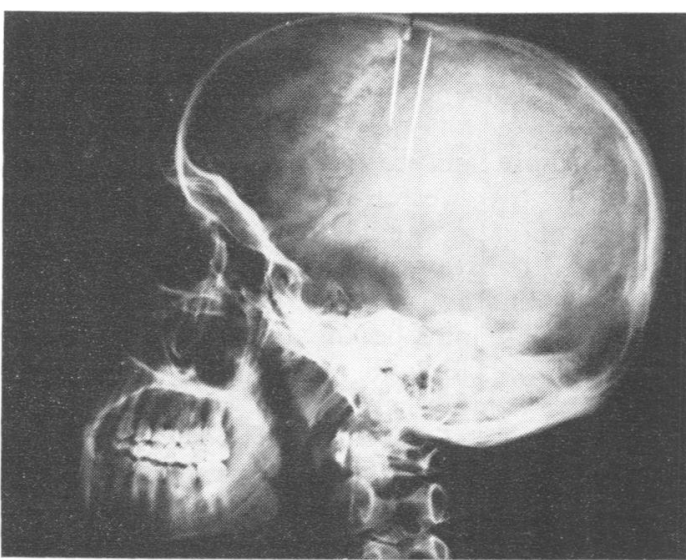

(a)

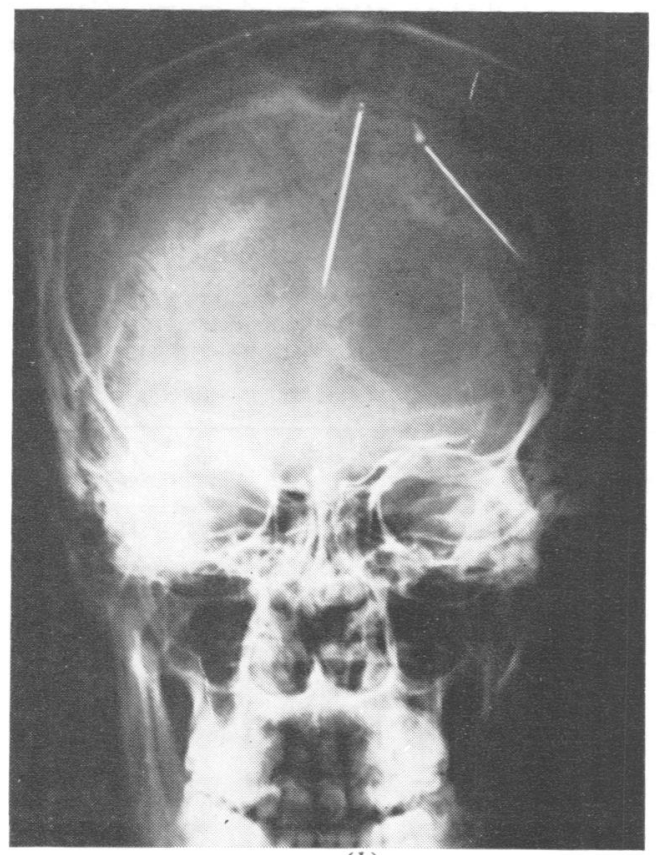

(b)

Fig. 1 (a) Lateral radiograph of skull of case 1. Two sewing needles near the coronal suture. Note fragmented upper end of the anterior needle.

(b) AP view of case 1. Note inclination of the left needle.

speech was practically normal.

Skull radiographs (Fig. 1a, b) showed two needles in the posterior frontal region, one vertical with slight inclination to the right and the other oblique towards the left interior frontal cortex. The upper ends of the needles were near the inner table of the skull, 10 and $30 \mathrm{~mm}$ from the midline under the coronal suture. Angiography and CAT scans did not demonstrate any other abnormalities. The needles were removed through a left frontal parasagittal craniotomy. The exposed cortical veins appeared thrombosed, explaining the patient's hemiparesis. The needles were encrusted with an irregular coating. The upper end of the lateral needle was separated from the main body and attached to the dura mater (Fig. 2).

After the operation the patient made a rapid psychological improvement. His headache disappeared, and his speech returned to normal. There has been a steady improvement of his hemiparesis.

CASE 2 (CASE 12 OF TABLE)

A young man was involved in a car accident and was seen by a general surgeon. Routine radiographs of the skull showed a single sewing needle in the midline of the posterior frontal region. In all other cases seen by us the upper ends of the needles were just under the inner table of the skull, but in this case it was at least $30 \mathrm{~mm}$ inside the skull. There was no surgical intervention and there has been no further follow-up.

CASE 3 (CASE 13 OF TABLE)

A boy, aged 4 months, had become irritable and febrile for a week before admission. Two days before admission he developed convulsions and on the day of admission he had vomiting and temperature of $40^{\circ} \mathrm{C}$. He was not alert and had rigidity of the muscles of the neck and extremities. There was a raised red patch over the anterior fontanelle.

Examinations of blood and CSF were in favour of a meningeal infection. Skull radiographs disclosed a solitary sewing needle in a vertical position under the anterior fontanelle. The needle was removed under local anaesthesia and through a small incision. Antibiotic and anticonvulsant drugs were administered. The patient made a complete recovery and was discharged after two weeks.

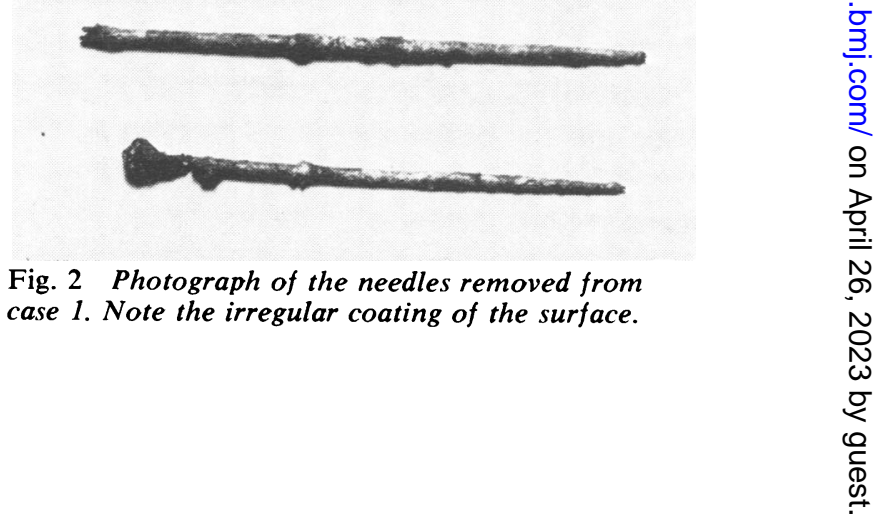


Further investigation disclosed that the first wife of the father was infertile, and the mother and child had been visiting her just before the onset of the baby's illness.

\section{Discussion}

Summaries of the 13 cases under review are given in the Table. There is no doubt that these needles have been introduced some time before closure of the fontanelles. In those cases with two needles we can certainly assume that they are examples of attempted infanticide. In those with one needle there is a minor possibility of accidental insertion, as in case 4 in the Table whose mother gave a dubious history of falling on the baby with the needle in her hand.

Case 8 from Yugoslavia claimed that an aunt of hers, at her death bed confession, stated that she had attempted to get rid of the patient in order to obtain her inheritance. Case 1 of the Table, a 4 day old baby was killed by the psychopathic mother who not only inserted the needle but also administered poison. In case 2 the stepmother was so cruel to the baby that the child had to be removed from home and left under the care of an uncle. In case 13, the mother and the child had visited the infertile stepmother just before the baby's illness. In other cases there was no definite evidence to indicate the perpetrator of the crimes.

Child abuse and battered babies, so often reported in the western media, have a fundamentally different cause-for example, alcoholism of parents, frustration at home, and so on. From the study of the cases we have been able to collect, which may be the tip of the iceberg, it seems that intracranial needling as a method of child abuse is more common as we go eastward.

Case 1 as already mentioned died from poisoning. In case 3 who died at age 70 years, the needle was an incidental finding at necropsy. Case 4 , a child of 16 months, was repor'ed by the mother as an accident. Case 11 (our case 1) was an incidental finding after head injury. Case 13 (our case 3 ) in the Table was diagnosed because of meningitis and convulsions. Eight other cases had late symptoms which were probably caused by the needles. The most common symptoms were headache and epilepsy. Headache was present in five cases, epilepsy in five cases, and hemiparesis was seen in only one case which cleared up after removal of the needle. The most interesting feature of the symptomatology in these patients is the

Table Review of 13 reported cases with intracranial sewing needles

\begin{tabular}{|c|c|c|c|c|c|c|c|c|}
\hline Case & $\begin{array}{l}\text { Age at } \\
\text { presentation }\end{array}$ & $\begin{array}{l}\text { Duration of } \\
\text { symptoms }\end{array}$ & Symptoms & $\begin{array}{l}\text { Number } \\
\text { of needles }\end{array}$ & Probable source & Author & Date & $\begin{array}{l}\text { Country of } \\
\text { birth }\end{array}$ \\
\hline 1 & $4 d$ & $4 \mathrm{~d}$ & $\begin{array}{l}\text { Died of poisoning and } \\
\text { inserted needle }\end{array}$ & 1 & $\begin{array}{l}\text { Psychopathic } \\
\text { mother }\end{array}$ & Meixner & 1914 & Hungary \\
\hline 2 & $43 \mathrm{yr}$ & $\begin{array}{l}\text { From } \\
\text { childhood }\end{array}$ & Epilepsy & 2 & Stepmother & Meixner & 1914 & Germany \\
\hline 3 & $70 \mathrm{yr}$ & - & Necropsy & 1 & - & Haun & 1927 & Germany \\
\hline 4 & $16 \mathrm{mo}$ & - & Reported by mother & 1 & ? Accident & $\begin{array}{l}\text { Gerlach and } \\
\text { Jensen }\end{array}$ & 1958 & USA \\
\hline 5 & $29 \mathrm{yr}$ & $\begin{array}{l}13 \mathrm{yr} \text { and } \\
8 \mathrm{yr}\end{array}$ & Headache and epilepsy & 2 & Illegitimate brother & $\begin{array}{l}\text { Gerlach and } \\
\text { Jensen }\end{array}$ & 1958 & Germany \\
\hline 6 & $23 \mathrm{yr}$ & $5 \mathrm{yr}$ & Epilepsy & 1 & - & $\begin{array}{l}\text { Askenasy } \\
\text { et al. }\end{array}$ & 1961 & Hungary \\
\hline 7 & $54 \mathrm{yr}$ & $2 \mathrm{yr}$ & Headache & 1 & - & $\begin{array}{l}\text { Askenasy } \\
\text { et al. }\end{array}$ & 1961 & Poland \\
\hline 8 & $32 \mathrm{yr}$ & $8 \mathrm{yr}$ & Epilepsy & 2 & Stepmother & $\begin{array}{l}\text { Ameli and } \\
\text { Alimoham- } \\
\text { madi }\end{array}$ & 1970 & Iran \\
\hline 9 & $31 \mathrm{yr}$ & $7 \mathrm{mo}$ & Headache and hemiparesis & 1 & - & $\begin{array}{l}\text { Ameli and } \\
\text { Alimoham- } \\
\text { madi }\end{array}$ & 1970 & Iran \\
\hline 10 & $56 \mathrm{yr}$ & $40 \mathrm{yr}$ & Headache & 1 & Aunt & $\begin{array}{l}\text { Popular } \\
\text { journal } \\
\text { (Bunte) }\end{array}$ & 1971 & Yugoslavia \\
\hline 11 & $24 \mathrm{yr}$ & $6 \mathrm{yr}$ & Headache & 2 & - & $\begin{array}{l}\text { Abbassioun } \\
\text { et al. }\end{array}$ & 1979 & Iran \\
\hline 12 & Adult & - & - & 1 & - & $\begin{array}{l}\text { Abbassioun } \\
\text { et al. }\end{array}$ & 1979 & Iran \\
\hline 13 & $4 \mathrm{mo}$ & $7 \mathrm{~d}$ & Meningitis and convulsions & 1 & Stepmother & $\begin{array}{l}\text { Abbassioun } \\
\text { et al. }\end{array}$ & 1979 & Iran \\
\hline
\end{tabular}


interval between the assumed age of the patient at the time of insertion and the onset of symptoms. The longest interval was in case 7 (52 years) and the shortest was in case 2 in whom epilepsy started in early childhood. In others the interval varied from 16 to 30 years. Duration of symptoms varied from seven months to 40 years. Of course we are dealing with cases who have survived the attempted infanticide. It is probable that many babies die by this method and the reason is never suspected. The causes of death are probably infection, thrombosis, and haemorrhage.

If the attempt is made by insertion of a safety pin, as the needle is not left in situ, the cause would not be detected without a careful necropsy. Except in case 4 which the mother reported, and cases 1 and 3 found at necropsy, all the other cases were diagnosed by skull radiography.

How does the brain tissue tolerate such a foreign body? It has been shown that metallic foreign bodies are much better tolerated in the brain than fragments of bone (Azariah, 1970; Hagen, 1971). At operation the needles are found to be surrounded by a thin fibrous tissue capsule containing xanthochromic fluid. The surface of the needle is covered by irregular deposits of iron phosphate (Ameli and Alimohammadi, 1970), one of the methods used in industry to make stainless steel. This is why the needles are so well preserved even after 70 years.

The physician's ethical attitude in the presence of such a diagnosis is rather difficult. In infants one can follow the line prescribed for other forms of child abuse-that is, to report the case to the proper authorities. But in an adult, even mention of such a possibility may cause a great deal of distress, and in any case no legal action is possible after a certain lapse of time. We, therefore, suggest that the patient should be told the truth but no explanation volunteered.

\section{References}

Ameli, N. O., and Alimohammadi, A. (1970). Attempted infanticide by insertion of sewing needles through fontanelles. Report of two cases. Journal of Neurosurgery, 33, 721-723.

Askenasy, H. M., Kosary, I. Z., and Braham, J. (1961). Sewing needles in the brain with delayed neurological manifestations. Journal of Neurosurgery, 18, 554-556.

Azariah, R. G. S. (1970). An unusual metallic foreign body in brain. Case report. Journal of Neurosurgery, 32, 95-99.

Dimitrijevic, D. (1971). Mordversuch mit her Nahnadel. Illustrierte, 22, 7.

Gerlach, J., and Jensen, H. P. (1958). Intrakranielle Nahnadeln-eine ungewohnliche ursache von kopfschmerzen. Zentralblatt für Neurochirugie, 18, 127-135.

Hagen, R. E. (1971). Early complications following penetrating wounds of the brain. Journal of Neurosurgery, 34, 132-141.

Haun, K. (1927). Beitrag zur Lehr vom Kindesmord. Deutsche Zeitschrift für Gerichtlicht Medizin, 10, 58-69.

Hedayat, S. (1951). Se Ghatreh Khoon (Three drops of blood). Amirkabir: Tehran. In Persian.

Meixner, K. (1914). Totungsursuchi an Kindern durch Einstechen von Nadeln in den Kopf. Deutsche Zeitschrift für Gerichtlicht Medizin, 47, 382-386. 